\title{
Value Chain of Exhaust Industry in Purbalingga Regency
}

\author{
Agus Arifin ${ }^{1}$ \\ \{arifin_ie@yahoo.co.id $\left.{ }^{1}\right\}$ \\ Economics and Development Studies Department, Jenderal Soedirman University, Indonesia ${ }^{1}$
}

\begin{abstract}
The exhaust industry is one of the industries located in Purbalingga Regency which is manufactured by the traditionally production process. The activities during all processes on this industry have built a value chain. This research aims to (1) investigate how to obtain all raw materials, (2) analyze how to market the products, and (3) analyze the value chain. Data were collected by interviews using questionnaire. The number of sample was 54 entrepreneurs through simple random technique. The value chain analysis is used to analyze the series of activities. The results show that (1) the raw materials are come from Tegal and own Purbalingga; (2) the marketing spreads to almost throughout Indonesia with three channels, i.e. through agents, direct to consumer, and through online sales; (3) The value chain is divided into three main activities, i.e. the process of obtaining raw materials, exhaust production process, and marketing process of the products.
\end{abstract}

Keywords: Value Chain, Exhaust Industry, Exhaust Craftsman

\section{Introduction}

At this time the international trade competition is very strict because it needs high competitiveness that is owned by industry to compete. One that can affect the competitiveness of an industry is the value chain. Through the effective value chain, an industry can obtain optimal performance in international trade competition [1]. The value chain is management where the business is seen as a chain of activities to change inputs into outputs so it has value for customers [2]. In the companay's value chain analysis is considered one part of the product value chain. The product value chain is formed due to the supplier linkages and relation with consumer linkages. This is a separate but interdependent activity of one another [3] [4].

The approach to value chain analysis is seen as the best approach in developing a company for better [5]. Companies that are viewed as one part of the production chain in the value chain analysis make it easier for managers to analyze the position of their company to improve competitive advantage. Competitive advantage can be obtained with effective value chains so that industry can produce added value for the industry [6]. The value chain is all the activities undertaken by an industry that is depicted from the purchase of raw materials (goods or services) and taken to the design venue, entering into a diverse production process (including the physical transformation and input of various service providers), thereafter marketed towards the end consumer and recycled after use. The efficiency of the costs incurred by the industry and the increase in value-added for consumers can also be obtained by the analysis of the value chain, through the activity stages in the value chain, so that industry becomes more competitive because of the cost efficiency and increased added value. 
Purbalingga Regency has several potential industries, namely the wig and false eyelashes industry. Besides these two industries, the exhaust industry in Purbalingga Regency is also quite promising. Its exhaust products have been marketed to almost all regions in Indonesia. The following are the number of small and medium industries in Purbalingga Regency.

Based on the table below can be known Purbalingga has the value of assets and large production capability in the exhaust industry. The condition shows that the exhaust industry in Purbalingga Regency is a potential industry. There are five villages such as the biggest exhaust centers such as Purbalingga Lor village, Kembaran Kulon, Mewek, Gembong, Galuh, and Kertanegara, where the area has high assets, capabilities, and become the pride of local people because it has a superior product in the form of exhaust.

The Department of Trade Industry and Cooperatives Purbalingga Regency even recorded the artificial exhaust of local people can market its products in the global automobile industry market such as BMW, Hartop, Chevrolet, Toyota, Isuzu, Daihatsu, Honda, Suzuki, Mitsubishi, Nissan, and Mercedes Benz. The motorcycle industry markets such as Honda, Suzuki, Vespa, Kawasaki Ninja, Yamaha F1 ZR, RX King, Mio, Honda Tiger, and Harley Davidson.

Table 1. Small and Medium Industrial Automotive and Metal Parts in Purbalingga Regency, 2014

\begin{tabular}{|c|c|c|c|c|c|}
\hline \multirow[t]{2}{*}{ No. } & \multirow[t]{2}{*}{ Village } & \multirow{2}{*}{$\begin{array}{l}\text { Number of } \\
\text { attempts }\end{array}$} & \multirow[t]{2}{*}{ Description } & \multicolumn{2}{|c|}{$\begin{array}{l}\text { Value (thousands of } \\
\text { Rupiah) }\end{array}$} \\
\hline & & & & Assets & Production \\
\hline 1. & Purbalingga Kulon & 3 & Home Appliances & 78,000 & 29,200 \\
\hline 2. & Purbalingga Lor & 61 & Exhaust & $2,037,135$ & $2,256,680$ \\
\hline 3. & Kembaran Kulon & 40 & Exhaust & $2,966,180$ & $2,600,070$ \\
\hline 4. & Wirasana & 8 & Home Appliances & 159,850 & $1,152,300$ \\
\hline 5. & Mewek & 1 & Exhaust & 59,500 & 4,800 \\
\hline 6. & Karang Jambe & 1 & Home Appliances & 15,500 & 86,350 \\
\hline 7. & Gemuruh & 1 & Home Appliances & 19,500 & 108,000 \\
\hline 8. & Karanglewas & 1 & Home Appliances & 22,500 & 31,200 \\
\hline 9. & Brobot & 2 & Home Appliances & 14,500 & 117,000 \\
\hline 10. & Gembong & 2 & Exhaust & 42,600 & 76,000 \\
\hline 11. & Galuh & 10 & Exhaust & 87,778 & 309,945 \\
\hline 12. & Patemon & 2 & Home Appliances & 39,500 & 180,000 \\
\hline 13. & Kajongan & 1 & Home Appliances & 2,500 & 3,888 \\
\hline 14. & Selaganggeng & 1 & Home Appliances & 2,320 & 4,800 \\
\hline \multirow[t]{2}{*}{15.} & Kertanegara & 140 & $\begin{array}{c}\text { Exhaust and Home } \\
\text { Appliances }\end{array}$ & 238,776 & $1,152,058$ \\
\hline & Total & 274 & & $5,786,139$ & $8,112,291$ \\
\hline
\end{tabular}

Most of the exhaust industry in Purbalingga is a small industry that is constrained in capital and technology. The limitations of capital and technology make the production process of exhaust in Purbalingga still relatively simple because it relies solely on handicrafts. Although with simple technology, the exhaust products from Purbalingga Regency can spread across almost all parts of Indonesia and can penetrate the global market. Uniqueness in the process of making the exhaust is an added value to the product of exhaust in Purbalingga and the quality produced is also not inferior to the production exhaust factory [8]. 
The increasingly strict industry competition at this time is a challenge for the industry to still survive. No exception the exhaust industry in Purbalingga should have high competitiveness so that it can continue to survive in the industry competition today. High competitiveness can be obtained through effective and efficient value chain analysis that can be applied to the exhaust in Purbalingga. Activities in the process of exhaust production in the range of raw material procurement, exhaust production process, and marketing of exhaust to consumers are key to the value chain of the exhaust product itself. The competitive advantage of a product can be identified through effective value chain analysis [9]. Value chain analysis activity focuses on a series of existing activities that must be maximized to generate maximum profit and increase the selling value for consumers. Important value chain analysis is done in industrial activity. All activities undertaken by the company both to design, obtain inputs, produce, market, and deliver goods need to be identified one by one in a value chain analyst. According to Porter [3], competitive advantage is not known if the understanding of the Company's activities is seen as a whole. Each activity in the unity of value chain activity contributes to its position so that each activity should provide additional value when the excitement runs effectively.

As the center of the exhaust industry, Purbalingga Regency able to provide quality products and can compete with factory-processed exhaust products. Actually, in the Purbalingga area, no metal industry provides the raw material for exhaust production. The need for raw materials needs to supply from outside the area. The selection of quality raw materials at an affordable price will certainly produce high quality and highly competitive exhaust. The need for value chain analysis is to know the most effective areas of raw material suppliers and how to transport the most efficient materials both in terms of cost, time, and energy. Value chain analysis is also beneficial to identify the most appropriate way of marketing so that profits can be maximized.

Based on the description, the focus of the objectives to be examined in this research are:

1) Analyzing the way the exhaust craftsmen in Purbalingga obtain raw materials and where the raw materials originated.

2) Detecting how to marketing the exhaust product in Purbalingga.

3) Analyzing the value chain of the exhaust product in Purbalingga.

\section{Literature Review}

The industry is a business or activity of processing raw materials or semi-finished goods into finished goods that have added value to obtain profits. Results in industrial activities can be in the form of service, not just in the form of goods. The industry is a livelihood activity that uses skills and work skills and uses a variety of facilities and infrastructure in the field of processing of agricultural products and their distribution as the basis. This makes the industry called part of the advanced link of activities to meet the needs (economy) related to the earth, namely after agriculture, plantation, and mining are closely related to the land.

The definition of industry according to Law No. 31 of 2000 Article 1 paragraph (1) is a creation of a shape, configuration, or composition of lines or colors, or lines and colors, combinations of them that are three-dimensional or two-dimensional, which gives the impression of Estesisi and can be used to produce a product, goods, industrial commodities, or handicrafts. 
The Central Statistic Agency states that the industry is a branch of economic activity, a company, or similar business entity where someone works. The Central Statistic Agency also classifies activities in the industry based on the number of labor, working into four, namely large industries, medium industries, small industries, and home industry. Based on the grouping that belongs to the large industry is the industry that employs a workforce of 100 people or more, the medium industry is an industry that hires 20 people up to 99 people, small industries is the industry that employs a workforce of 5 people up to 19 people, and the home industry is an industry that hires labor of 1 person up to 4 people.

\subsection{Production}

The production function is an equation that shows the dependency (functional) relationship between the level of input used in the production process and the level of output produced. Systematic production functions can be stated as follows:

$$
Q=f(K, L, R, T)
$$

Where:

$\mathrm{Q}=$ The amount of production produced by various types of factors of production are used

$\mathrm{K}=$ The amount of available capital

$\mathrm{L}=$ The amount of available labor

$\mathrm{R}=$ Natural wealth

$\mathrm{T}=$ Technology

Based on the above equation, it means that the amount of production of goods or services depends on how much capital, labor, natural resources are used, and the technology used during the production process.

When analyzing the production process the factor of production is considered fixed, it aims to facilitate the analysis process unless it is known. Factors of production that are considered fixed are called constant factors of production, while factors of production that can change in quantity during the production process are called variable factors of production. In a production process, if there are constant factors of production and variable factors of production, the production process is a short-term production process. Whereas if all production factors are variable in the production process, the production process is a longterm production process [10].

\subsection{Value Chain}

The value chain is the whole chain of activities to change inputs into outputs so that it has more value for a customer [11]. The value chain runs from the initial activity of obtaining raw materials to post-sale handling. More value from customers is based on three main activities, namely activities that make products have more value than other products, activities that have the advantage of lower product costs, and activities that can quickly meet customer needs. Overall this value chain analysis serves to identify the stages that provide the greatest added value to consumers and minimize costs incurred [12] [13].

The value chain analysis can also help the business actor to understand how to position their business activities in the value chain to enhance competitive advantage. Activities in the value chain must be thoroughly assessed whether to add additional value to each chain. If the activity provides additional value, it needs to be maximized. Value chain analysis is a 
technique of analysis in a business, by observing the contribution to all activities that occur in the business so that it can produce value for customers [2].

The value chain analysis is divided into two groups of activities, namely the main activity and supporting activities. Activity in the value chain starts from the input obtained by the company, then the process of production, marketing of goods or services produced by the company, and finally the after-sales service for customers. This value chain analysis attempts to observe the cross costs in each sequence of activities that occur in the business to determine where there are low-cost advantages or cost weaknesses [14] [15].

The value chain analysis examines each attribute in various value chain activities to ensure the right way in each activity that occurs when purchasing inputs and after-sales services can differentiate the company's products and services. Value chain analysis can help the business actor to better identify a company's competitive advantage by assuming that companies are part of the process chain of activities that takes place in business [16].

The value chain analysis also provides benefits to explain to whom the benefits can be distributed. This analysis can also make it easier to identify which policies are suitable for implementation in a value chain cycle [13]. Similarly, in the exhaust industry, the use of value chain analysis is expected to be able to maximize the value-added of exhaust products and increase business profits.

\subsection{Marketing}

Marketing is one of the activities in the economy to produce economic value. This economic value is related to determining the price of goods and services from a product sale. Marketing becomes very important because this activity bridges between production and consumption activities [17]. Good marketing activities are also based on a good management system. Marketing management can be interpreted as a process that includes analysis, planning, implementation, control, and the distribution of ideas, goods and services in order to produce satisfaction to the various parties involved in it. There are several things that need to be considered so that marketing management can run well, including the functions of planning, implementation, analysis, and supervision [17].

Marketing is one of the activities in the economy to produce economic value. This economic value is related to determining the price of goods and services from a product sale. Marketing becomes very important because of this activity bridges between production and consumption activities [17]. Good marketing activities are also based on a good management system. Marketing management can be interpreted as a process that includes analysis, planning, implementation, control, and the distribution of ideas, goods, and services to produce satisfaction to the various parties involved in it. Several things need to be considered so that marketing management can run well, including the functions of planning, implementation, analysis, and supervision [17].

According to Stanton [18], marketing is a business activity in which there are planning, pricing, promoting, and transferring goods or services to buyers in satisfying their needs. A company that produces both goods and services must carry out marketing activities to maintain business continuity. Marketing activity is an activity that is directly related to consumers and related to the market. As stated by Kotler [19] that marketing is an activity with the market to create potential exchanges and meet human needs, then marketing is the key to a company's success. 


\section{Method}

The type of this research is descriptive qualitative, qualitative descriptive research is a research method that seeks to describe and describe various phenomena that exist, both natural and human engineering, which is more concerned about the characteristics, quality, interrelationships between activities. Besides, descriptive research does not provide treatment, manipulation, or alteration of the variables studied, but rather illustrates a condition as it is [20]. The target of this research is the exhaust producers in Purbalingga Regency and the Department of Trade Industry and Cooperatives as an office related to industrial development in the Purbalingga Regency. The data collected in this research uses observation and interview methods. The observation method is carried out by conducting direct observations during research activities in Purbalingga Regency to obtain information and supporting data from both producers and consumers. The interview method is carried out by asking several questions that have been prepared in the questionnaire. Sources of data from this study consisted of primary data and secondary data. Primary data is data obtained in research by conducting direct interviews using a list of questions that have been prepared in advance. Primary data were obtained from direct interviews with exhaust producers in Purbalingga Regency. Secondary data is data obtained from other parties or data sources that already exist both from literature studies, agencies, or institutions related to this research. The secondary data in this study were obtained from the Central Statistics Agency and the Department of Trade Industry and Cooperatives. The population in this study was 114 exhaust producers in Purbalingga Regency. In this study, the sampling method used was Simple Random Sampling. The method for determining the sample used is the Slovin formula [21]. The results of calculations using the Slovin method obtained a sample size of 54 exhaust craftsmen. Conceptual and Operational Definitions

Table 2. Conceptual and Operational Definitions

\begin{tabular}{|c|c|}
\hline Variable & Operational Definition \\
\hline Value Chain & $\begin{array}{l}\text { A value chain is a series of activities Value chains are strategies used to } \\
\text { carried out by a company to produce a understand competitive advantage by } \\
\text { product or service. Activities in the value identifying all company activities and } \\
\text { chain are divided into two, namely to understand the company's } \\
\text { primary activities and support activities relationships with suppliers and } \\
\text { [3]. } \\
\text { consumers. }\end{array}$ \\
\hline
\end{tabular}

\section{Results And Discussion}

\subsection{Results}

\subsubsection{Profile of Small Exhaust Industry in Purbalingga Regency}

The exhaust industry in Purbalingga Regency started from the metal industry from zinc and drums for the manufacture of household appliances located in Sayangan Hamlet, Purbalingga Lor Village, in the 1970s. In its development in 1980, residents started to produce motorcycle and car exhausts, the industry has continued to grow until now it has spread to surrounding villages in Purbalingga Regency. 
During this time Purbalingga exhausts are mostly made in handmade or handicrafts. In its development, nowadays craftsmen also utilize production equipment such as pound, banding, and cutting machines to improve the quality of exhaust. The exhaust industry in Purbalingga Regency is scattered in several areas in Purbalingga Regency, here are the craftsmen data in Purbalingga:

Table 3. Data of CraftsMen in Purbalingga

\begin{tabular}{|c|c|c|}
\hline No. & Village & $\begin{array}{c}\text { Number of } \\
\text { Craftsmen/Entrepreneurs } \\
\end{array}$ \\
\hline 1. & Purbalingga Lor & 61 \\
\hline 2. & Purbalingga Kulon & 40 \\
\hline 3. & Gembong & 2 \\
\hline 4. & Mewek & 1 \\
\hline 5. & Galuh & 10 \\
\hline & Total & 114 \\
\hline
\end{tabular}

This research was conducted on exhaust entrepreneurs in the Purbalingga Regency. The exhaust business in Purbalingga is a home industry and spreads in various Purbalingga regions. The results showed that most of the craftsmen had become exhaust entrepreneurs in less than 5 years at 50 percent, between $6-10$ by 35.19 percent and the remaining 14.81 percent were respondents who had been exhaust craftsmen for more than 10 years.

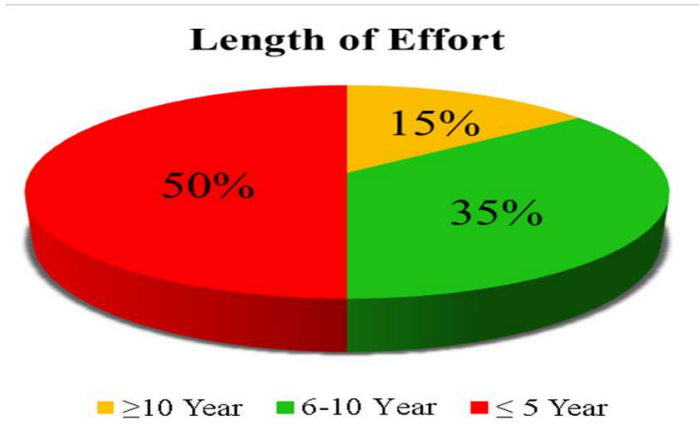

Fig.1. Length of Effort of Exhaust Entrepreneur in Purbalingga Regency

The level of education of craftsmen in Purbalingga Regency is appropriate as the average respondent at the junior high school and senior high school level. Figure 2 can be seen that the most exhaust craftsmen are senior high school graduates with a percentage of $41 \%$, the second is junior high school graduates with $37 \%$, so on are elementary school graduates by $18 \%$ and undergraduate graduates by $4 \%$. Based on the story of the craftsmen during the interview, the craftsmen have known the exhaust industry since they were kids so that after taking sufficient education they prefer to continue their business in the exhaust industry rather than continuing to higher education. 


\section{Percentage of Education}
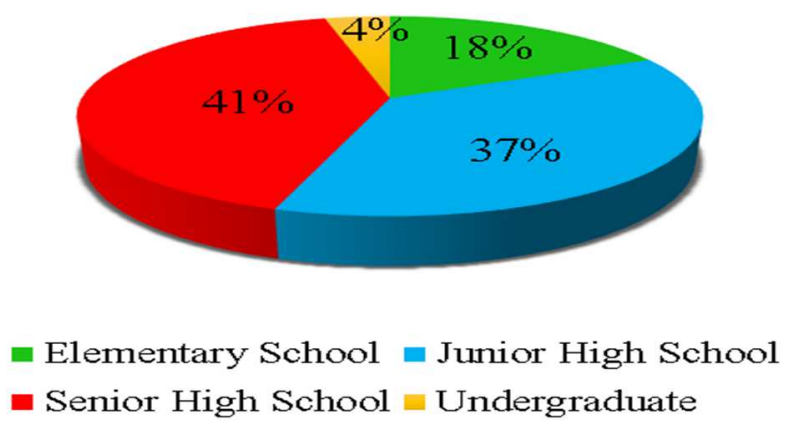

Fig.2. Percentage of Respondent Education

\subsubsection{The Exhaust Manufacturing Process}

The exhaust products in Purbalingga Regency are rated as quality exhaust, here are the stages in making exhaust:

a. Mal/Printing

Mal or printing is the initial stage of making the exhaust, usually, the printing is done using the original exhaust so that the plate material is printed based on the original exhaust size. This is done to obtain the right holder so that no errors occur in the next process.

b. Cutting

Cutting of plate material from both galvanized and stainless is done after the mal/printing is finished then cut carefully so that when welding does not experience difficulties.

c. Formation

At the stage of formation must be done carefully to the plate that has been cut. The process of forming is done by knocking, the formation of the plate is very important so that the resulting exhaust shape is appropriate

d. Welding

When the welding process requires patience, accuracy, and tidiness so that during the leveling process does not experience difficulties and of course produces quality products.

e. Flattening

After the various plate processes have been shaped as an exhaust, to be a better exhaust the leveling process is carried out. Usually, when welding there are uneven shapes, it is flattened in this process.

f. Sorting

After going through various stages of the exhaust is sorted again and selected the best exhaust. This sorting must be done very carefully so that products on the market do not experience defects both from the way of welding and from the formation of the exhaust.

g. Finishing

Finishing is the final stage of making the exhaust after being sorted and then filled with gas bol, after filling the gas bol is complete then the exhaust product is ready to be marketed. 


\subsubsection{Value Chain of Exhaust Industry in Purbalingga}

Before starting to produce exhaust, craftsmen must buy all the necessities/materials used during the exhaust production process. It takes precision and caution when choosing raw materials because the raw material is the key to an exhaust product into a quality product. Quality of quality exhaust products will be produced from the selection of raw materials that are well-qualified.

Capital becomes a differentiator in the process of purchasing exhaust raw materials, craftsmen with more capital will have a large production capacity also. Such craftsmen will usually buy raw materials directly to the store, not at the collector's place, this is due to the consideration of lower price margins when buying directly to the store. Craftsmen who are constrained in the capital with insufficient production capacity tend to buy at collectors.

a. Raw material

Metal is the main raw material in making exhaust products. Two types of metals are often used in the process of making an exhaust, namely stainless and galvanized. The purchase of both materials is usually still in raw form, which is still in the form of a plate or sheet. Apart from these two raw materials, craftsmen also need materials in the form of stainless pipes that are divided into various inches. Exhaust craftsmen can get these materials directly from the shop or collectors, the purchase of raw materials is adjusted to the needs of the craftsmen and also the available capital. Here are the details of the price of the raw material exhaust.

Table 4. Price of Raw Materials

\begin{tabular}{clr}
\hline \multicolumn{3}{c}{ Table 4. Price of Raw Materials } \\
\hline No. & \multicolumn{1}{c}{ Type of Material } & $\begin{array}{c}\text { Average Price } \\
\text { (in Rupiahs) }\end{array}$ \\
\hline 1. & Stainless & 442,000 \\
2. & Galvanized & 362,000 \\
3. & Pipe & 244,000 \\
\hline
\end{tabular}

b. Acquisition Area of Exhaust Craftsmen

The exhaust raw material is obtained locally from Purbalingga and out of town, one of which is Tegal. The location of obtaining raw materials that are located close enough to benefit the craftsmen because they are easy to reach and do not require more costs for transportation.

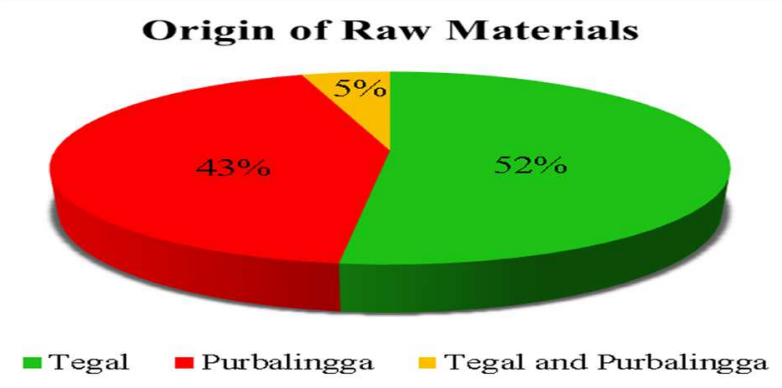

Fig.3. Origin of Raw Materials 
Based on the figure of the diagram above, it can be seen as many as 52 percent of respondents get exhausted raw material from the Tegal, 43 percent from Purbalingga, while 5 percent of the two regions both Purbalingga and Tegal.

The transportation equipment used in transporting raw materials is adjusted to the distance and also the number of raw materials transported. Transportation of raw materials originating from local areas usually uses pedicabs, motorcycles, or pickups. For transportation of raw materials originating from outside Purbalingga by transporting large quantities of raw materials, usually using trucks.

c. Production capacity per day (unit)

Here is the data on production capacity that can be produced by respondents:

Table 5. Production Capacity of Respondents

\begin{tabular}{|c|c|c|c|}
\hline No. & $\begin{array}{l}\text { Production capacity } \\
\text { (unit) }\end{array}$ & Frequency & Percentage \\
\hline 1. & $1-5$ & 24 & 44.44 \\
\hline 2. & $6-10$ & 23 & 42.59 \\
\hline 3. & $>10$ & 7 & 12.96 \\
\hline \multicolumn{2}{|r|}{ Total } & 54 & 100.00 \\
\hline
\end{tabular}

The results showed that most of the exhaust craftsmen in Purbalingga were able to produce exhaust every day between 1-5 pieces in the amount of 44.44 percent and 6-10 pieces in the amount of 42.59 percent. Besides, there are craftsmen with the ability to produce exhaust more than 10 pieces per day as much as 12.96 percent. The limited capacity of the products produced is because most of the exhaust craftsmen have not used technology that can produce products faster. During this time respondents used to make the exhaust business as a homemade business with traditional tools. The production process is not done every day usually within one week of effective production is 4 or 5 days.

d. Number of Labor Absorbed

In their production activities, craftsmen use the entire labor from the region in Purbalingga itself. The following is the number of workers employed in the exhaust production process in the home industry in Purbalingga Regency.

Table 6. The Number of Workers Involved in The Exhaust Production Process

\begin{tabular}{cccc}
\hline No. & Total Labor & Frequency & Percentage \\
\hline 1. & $1-5$ & 44 & 81.48 \\
2. & $6-10$ & 9 & 16.67 \\
3. & $>10$ & 1 & 1.85 \\
\hline \multicolumn{2}{c}{ Total } & 54 & 100.00 \\
\hline
\end{tabular}

Based on the results of the study, it can be seen that most or as much as 81.48 percent of craftsmen in the exhaust home industry in Purbalingga use the labor of between 1-5 people. Besides, there are exhaust craftsmen who use labor between 6-10 people by 16.67 percent, and the rest only 1.85 percent use the labor of more than 10 people. Based on the results of the study note that all respondents use local labor to reduce labor costs so that business operations are more efficient. The exhaust industry in Purbalingga can be classified as a home industry based on the Central Statistics: it employs 1-5 people. 
e. Costs of Production Operational

The cost of production operational is the entire cost element needed during the production process of making exhaust. The operational costs of production consist of the costs of raw materials, labor, and so forth. The following are the production operational costs incurred during the process of making exhaust.

Table 7. Average Costs of Operational Production Incurred in The Process Exhaust Production

\begin{tabular}{ccrr}
\hline No. & $\begin{array}{c}\text { Average costs of operational } \\
\text { production (in Rupiahs) }\end{array}$ & Frequency & Percentage \\
\hline 1. & $100.000-200.000$ & 9 & 16.67 \\
2. & $200.001-300.000$ & 22 & 40.74 \\
3. & $>300.000$ & 23 & 42.59 \\
\hline & Total & 54 & 100.00 \\
\hline
\end{tabular}

Based on the results of the study, it can be seen that the amount of operational costs incurred by the exhaust craftsmen in the exhaust production process is more than $\mathrm{Rp}$ 300,000 , and the amount stated by 42.49 percent of respondents. Besides, some craftsmen spend operational costs between $\operatorname{Rp} 200,001$ - Rp 300,000 which is equal to 40.74 percent, then the remaining 16.67 percent are craftsmen who incur operational costs in the exhaust production process between $\mathrm{Rp} 100,000$ and Rp 200,000.

f. Standardization of The Process of Making Exhaust

Every entrepreneur naturally wants to make the best product and standardize it so the product that reaches the consumer has a good standard of eligibility. Following is the standardization of the process of making exhaust in exhaust craftsmen in Purbalingga Regency.

Table 8. Standardization of Exhaust Production in Home Industry in Purbalingga Regency

\begin{tabular}{ccrr}
\hline No. & $\begin{array}{c}\text { Standardize the process } \\
\text { of making exhaust }\end{array}$ & Frequency & Percentage \\
\hline 1. & Yes & 38 & 70.37 \\
2. & No & 16 & 29.63 \\
\hline & Total & 54 & 100.00 \\
\hline
\end{tabular}

The results showed that most or 70.37 percent of exhaust craftsmen already had standardized exhaust products. This aims to ensure that the exhaust product is indeed feasible up to the hands of consumers. Some items that are checked include exhaust tidiness, the shape of the exhaust, and the sound produced.

g. Average Selling Price

The results showed that respondents' exhaust sales were quite varied. Three craftsmen sold exhaust products with a price range of $\mathrm{Rp} 0$ to $\mathrm{Rp} 300,000$. Respondents who sell exhaust range in price between $\mathrm{Rp} 300,0001$ - Rp 600,000 there are 23 craftsmen, there are also those who sell a price range of Rp 600,001 - Rp 900,000 there are 15 craftsmen. The remaining 13 craftsmen sell exhaust with a price range of Rp900,001-Rp1,200,000.

Table 9. Average Selling Price of Exhaust in the Home Industry in Purbalingga Regency

\begin{tabular}{|c|c|c|c|}
\hline No. & Average Selling Price (in Rupiahs) & Frequency & Percentage \\
\hline 1. & Rp0 - Rp300,000 & 3 & 5.56 \\
\hline 2. & Rp300,001 - Rp600,000 & 23 & 42.59 \\
\hline 3. & Rp600,001 - Rp900,000 & 15 & 27.78 \\
\hline 4. & Rp900,001 - Rp1,200,000 & 13 & 24.07 \\
\hline
\end{tabular}


h. Sales in One Month
The following are sales data on the exhaust home industry in Purbalingga Regency:

Table 10. Sales of Exhaust on Home Industry in Purbalingga Regency

\begin{tabular}{ccrr}
\hline No. & $\begin{array}{c}\text { Sales in One Month } \\
\text { (Unit) }\end{array}$ & Frequency & Percentage \\
\hline 1. & $10-20$ & 20 & 37.04 \\
2. & $21-30$ & 25 & 46.30 \\
3. & $>31$ & 9 & 16.67 \\
\hline & Total & 54 & 100.00 \\
\hline
\end{tabular}

Based on research results, it is known that most or as many as 25 people ( 46.30 percent) can sell exhaust in one month between 21-30 pieces. Besides, there is 37.04 percent of respondents who can sell exhaust between 10-20 pieces each month and the remaining 16.67 percent can sell more than 31 exhaust.

i. Location of Sale

Not only marketed in the production area, but Purbalingga's exhaust products from Purbalingga's exhaust craftsmen are also marketed to almost all regions of Indonesia. This is because not only the quality is good, but the price is also relatively cheap so that consumers are interested. Purbalingga exhaust products are not only marketed on the island of Java, but also other islands. Because of its extensive marketing so this product is increasingly known by many people.

Table 11. Location of Exhaust Industry in Purbalingga Regency

\begin{tabular}{ccrr}
\hline No. & Location of sale & Frequency & Percentage \\
\hline 1. & Domestic & 52 & 96.30 \\
2. & Overseas & 2 & 3.70 \\
\hline & Total & 54 & 100.00 \\
\hline
\end{tabular}

The results showed that the sales of exhaust in the exhaust home industry in Purbalingga Regency were mostly in the domestic, namely amounting to 93.30 percent. Specifically, the marketing of exhaust products has reached all regions throughout Indonesia, such as Special Capital Region of Jakarta, Bekasi, Banten, Tangerang, Bandung, Bogor, Tangerang, Semarang, Solo, Purwokerto, Kebumen, Banjarnegara, Wonosobo, Pemalang, Special Region of Yogyakarta, Malang, Surabaya, Bali, Medan, Padang, Lampung, Kalimantan, Sulawesi.

Purbalingga's exhaust is a superior product that has customers from various regions. This product is the result of handicraft produced by the exhaust craftsmen in Purbalingga which is ultimately in demand by the market. Special Capital Region of Jakarta is the city that orders the most exhaust products based on what the craftsmen said. No wonder because Special Capital Region of Jakarta is the capital of Indonesia whose citizens have high mobility so that the need for automotive parts also increases. Based on the research results, it is also known that 3.70 percent of the marketing of exhaust which is a home industry in the Purbalingga Regency has expanded to overseas countries such as Japan, Malaysia and, Thailand.

j. How to Marketing

The exhaust craftsmen in Purbalingga usually already have their customers. The craftsmen have various ways to marketing their products and usually, they use more than one way to 
market it. The results showed that the marketing methods carried out by most producers were through the internet, namely amounting to 48.15 percent.

Table 12. How to Marketing the Sales of Exhaust Industry in Purbalingga Regency

\begin{tabular}{clrr}
\hline No. & How to Marketing & Frequency & Percentage \\
\hline 1. & Through agent & 7 & 12.96 \\
2. & Direct to consumers & 21 & 38.89 \\
3. & Internet & 26 & 48.15 \\
\hline & Total & 54 & 100.00 \\
\hline
\end{tabular}

Along with the development of technology, many Purbalingga residents have already used an android mobile or smartphone in their daily lives, especially in young citizens. This of course has an impact on sales of exhaust products. Many young people in Purbalingga sell products online by utilizing social media such as Facebook and Instagram.

Based on the results of the study also found that there is 38.89 percent of respondents who make direct sales into the hands of consumers. Craftsmen usually get orders directly by consumers according to the shape and sound of the desired exhaust. Sales of exhaust products directly to consumers do not bring much profit because consumers only use it for personal use.

The results showed there was 12.96 percent of the exhaust industry that sold its products through agents. The craftsman considers that the way of marketing through an agent is the most profitable way for them because agents already have automotive store subscriptions, so the number of orders is far more. With the increasing number of orders, the craftsmen will get even greater profits.

k. Product Marketing Constraints

In every business activity, of course, there are obstacles, including activities related to product marketing. Likewise, the exhaust industry in Purbalingga Regency. The following are various obstacles encountered in the field of marketing the exhaust products.

Table 13. Obstacles of Exhaust Marketing in Purbalingga Regency

\begin{tabular}{clrr}
\hline No. & Marketing Constraints & Frequency & Percentage \\
\hline 1. & Nothing & 21 & 38.89 \\
2. & Price competition & 11 & 20.37 \\
3. & Product competition & 6 & 11.11 \\
4. & Number of similar industries & 7 & 12.96 \\
5. & Innovation & 9 & 16.67 \\
\hline \multicolumn{2}{c}{ Total } & 54 & 100.00 \\
\hline
\end{tabular}

The results showed there was 38.89 percent of respondents who stated that they had no problems while marketing the exhaust. However, there was 20.37 percent who stated that the obstacle they faced in the activity was the price problem, where many other manufacturers offered their products at lower prices. Besides, there are 16.67 percent of respondents stated that the obstacles they face when marketing is innovation related to product innovation and marketing innovations that are often beyond their ability due to lack of knowledge, especially those related to technology. Besides, there was 12.96 percent stated that the obstacles they faced were the number of similar industries that had arisen in Purbalingga and 11.11 percent stated that the obstacles faced in marketing were product competition. 


\section{Product Warranty}

A guarantee is a guarantee given by the manufacturer to the purchaser, which guarantees that the goods purchased are not damaged or defective, and promises to repair or replace the goods given if there is damage to the goods or the goods do not function within a certain period. Following is the statement of the exhaust craftsmen in the exhaust home industry in the Purbalingga Regency.

Table 14. Product Guarantee provided by Purbalingga Regency Exhaust Industry

\begin{tabular}{|c|c|c|c|}
\hline No. & Product Warranty & Frequency & Percentage \\
\hline 1. & Have & 24 & 44.44 \\
\hline 2. & Have Not & 30 & 55.56 \\
\hline & Total & 54 & 100.00 \\
\hline
\end{tabular}

The results showed there were 30 respondents (55.56 percent) who stated that they did not provide guarantees or guarantees for the purchase of exhaust made by consumers. While 24 respondents (44.44 percent) stated that they provide guarantees, especially exhaust damage and functions that can be exchanged for new goods.

m. Form of Cooperation With Value Chain Actors

Business partnerships in the value chain are important to do business continuity, increase partner group resources, and also increase business scale. The following is a form of cooperation developed by the exhaust industry in Purbalingga with value chain actors.

Table 15. Form of Exhaust Industry Cooperation with Value Chains

\begin{tabular}{ccrr}
\hline No. & Form of Cooperation & Frequency & Percentage \\
\hline 1. & Fixed Supplier & 51 & 94.44 \\
2. & Has Not & 3 & 5.56 \\
\hline & Total & 54 & 100.00 \\
\hline
\end{tabular}

The results showed that most respondents or 94.44 percent stated that the form of work they do with the value chain is a fixed supplier, especially in the procurement of raw materials. This is to make it easier for them to obtain raw materials, get discounts, and even payment models that can be futures and easier to sell the exhaust products produced.

n. Business Constraints

The development of the exhaust industry in Purbalingga Regency still faces constraints such as limited capital, production techniques, raw materials, marketing, technology management, limitations in accessing market information, and network limitations

Table 16. Obstacles of Exhaust Industry in Purbalingga Regency

\begin{tabular}{ccrr}
\hline No. & Business Constraints & Frequency & Percentage \\
\hline 1. & Have & 36 & 66.67 \\
2. & Have Not & 18 & 33.33 \\
\hline & Total & 54 & 100.00 \\
\hline
\end{tabular}

The results showed that most respondents or 66.67 percent said they had problems in the exhaust industry, while the remaining 33.33 percent said they had no problems in the exhaust business.

There are many obstacles faced by respondents in the exhaust industry business in Purwokerto such as the difficulty of finding raw materials at affordable prices to be able to produce exhaust at competitive prices. Besides, the quality of human resources is also still 
inadequate because employees are still not serious in running their activities such as playing cellphones and being absent from work.

Another obstacle faced is the unavailability of technology that can produce exhaust faster with good quality, the many competitors offering products at varying prices and even lower prices, and also the marketing problems that have not been maximized other than because of lack of technical knowledge.

Although there are many obstacles, respondents stated that the exhaust business in the future will get better and will not stop because from time to time vehicles will appear, both motorcycles and cars with new types. Besides, the good quality of Purbalingga's exhaust production is still in high demand and will continue to grow due to the high level of good innovation that continues to emerge. In the future, the exhaust business will remain stable and even grow accompanied by the development of the motorcycle community, and the number of events that vehicles specifically relate to exhaust modification.

Even though the potential of the exhaust business is getting better and promising, overall the respondents stated that there are no institutions that have a special role in the business activities and there are no institutions that support the process of making exhaust.

\subsection{Discussion}

The results found that the exhaust industry in Purbalingga Regency was still classified in the small industry and home industry. In this study, the average number of workers was 1-5 people and 6-10 people in each exhaust workshop and only 1 exhaust workshop with more than 10 workers. Based on these findings the exhaust industry is a small industry and a home industry according to the Central Statistics Agency grouping. The exhaust industry is very important for the exhaust business because quite a lot of people depend on the exhaust industry as their main livelihood.

In the value chain, there are three very important activities, the three activities are the input of raw materials, production processes, and product marketing. The three activities were also applied to the exhaust industry in Purbalingga Regency, namely obtaining raw materials needed in the manufacture of exhaust, exhaust production processes, and marketing of exhaust products.

In making an exhaust, the materials used are obtained from material supply stores, not directly from the manufacturer. This is because these materials in the form of stainless plates and galvanized plates are waste that is not used by large factories. The materials obtained from the store are then distributed to craftsmen through the transportation of goods.

In the process of making an exhaust, raw materials in the form of stainless or galvanized sheets can be changed into an exhaust product that has a high selling value to provide the highest added value for the exhaust product. After the exhaust product is finished, the packaging process is carried out so that it adds to the selling value of the product. In the exhaust industry value chain activities, businesses have an important role in creating consistency in the exhaust industry, as evidenced by quality products and relatively low prices. This has become the main strength of the exhaust industry in Purbalingga. This is in line with Wijaya's [8] research, that the superiority of exhaust products lies in the quality of the product, shape, and color, as well as low prices. Besides, the exhaust industry in Purbalingga has another uniqueness, namely, consumers can easily order the exhaust according to their wishes. in competing with the exhaust of other brands, customer satisfaction is the main key in the competition.

Many consumers are interested in exhaust products from Purbalingga because the price is relatively cheap. The craftsmen get easy access to raw materials that come from Tegal and 
Purbalingga and coupled with the services of collectors who are ready to provide raw materials. Ease in obtaining raw materials for making exhaust that will reduce the costs incurred in exhaust production activities so that the exhaust sales price becomes cheap.

In exhaust production activities, craftsmen use the services of the Regional Technical Implementation Unit of Metal Coloring because the production section cannot be done alone. As explained by Wijaya [8], the uniqueness of exhaust products as an automotive component lies in the work done conventionally using hand skills. The exhaust production process runs quite effectively because of the work specialization that is applied and runs smoothly so that no significant obstacles are found during the exhaust production process. An effective production process can also minimize costs in the production process [22].

Another uniqueness in the exhaust value chain activity in Purbalingga is that there is no need for large-scale marketing advertising activities which are generally carried out on other products. The results showed that marketing is only done through social media such as the internet to make maximum product sales. Besides, because the Purbalingga exhaust is well known and already has many customers. Using the exhaust industry label from Purbalingga is enough to convince many parties to use the Purbalingga exhaust product. The high number of sales without promotion costs provides the potential for increased profits for the exhaust craftsmen.

\section{Conclusions}

\subsection{Conclusion}

In general, research on the analysis of the exhaust industry value chain in Purbalingga

Regency has several conclusions, including:

1. Exhaust craftsmen in Purbalingga get raw materials both from local Purbalingga and outside the city, namely Tegal.

2. The marketing of exhaust products is very wide in almost all of Indonesia with the most consumers in Java and several big cities outside Java. The pattern of marketing is done in three ways, namely through agents, directly to consumers, and through the internet (online sales).

3. The value chain activities in the exhaust industry in Purbalingga are divided into three main activities, namely the process of acquiring exhaust, the production process of exhaust, and the marketing process of exhaust products to the final consumer.

\subsection{Implication}

a) Considering the expansion of raw material acquisition not only in Tegal and Purbalingga but also from other regions so that information on raw prices from these other regions is obtained.

b) Increase the optimization of the use of social media such as Facebook, Instagram, and Youtube as a marketing tool, so that it can be seen by users of social media and can reach all of Indonesia and abroad.

c) Exhaust industry business actors in Purbalingga can make the value chain analysis a consideration in their efforts to be efficient and strengthen their business competitiveness. 


\section{References}

[1] Nurimansyah, 2011. Analisis Rantai Nilai (Value Chain) industri Pakaian Jadi di Indonesia. Thesis MM UGM, Yogyakarta.

[2] Pearce, A John dan Robinson. 2014. Manajemen Strategis. Salamba Empat. Jakarta.

[3] Porter, Michael E, 2005. Strategi Bersaing: Teknik Menganalisis Industri dan Pesaing, Erlangga, Jakarta.

[4] Widarsono, Agus. 2007. "Pengaruh Kualitas Informasi Manajemen terhadap Kinerja Manajerial (Survey Pada Perusahaan Go-Publik Di Jawa Barat)" Jurnal Akuntansi Fe Unsil, Vol. 2, No. 2.

[5] Weiler, Jhon, Schemel, Nelson. 2004. Value Chain And Value Coalitions, ICH White paper.

[6] Kaplinsky, R. and Morris, M. 2002. A Handbook for Value Chain Research. Brighton, United Kingdom, Institute of Development Studies, University of Sussex.

[7] Department of Trade Industry and Cooperatives. 2014. Pusat Data dan Sistem Informasi. Rekap Industri Kecil dan Menengah (IKM) Komponen Otomotif dan Logam Kabupaten Purbalingga Tahun 2014.

[8] Wijaya, A.A. 2015. Analisis Kesiapan Industri Knalpot Kelurahan Kembaran Kulon Sebagai One Village One Product (OVOP) di Kabupaten Purbalingga Provinsi Jawa Tengah. Skripsi. Yogyakarta: Fakultas Geografi, Universitas Gadjah Mada.

[9] Friska. S. 2010. Value Chain Analysis (Analisis rantai nilai) untuk keunggulan kompetitif Melalui Keunggulan Biaya. Jurnal Ekonomi. 13(1). 36-44.

[10] Faried, Wijaya. 1991. Sesi Pengantar Ekonomika Ekonomikamikro. BPFE. Yogyakarta.

[11] Dekker, Henri C. (2003). Value Chain Analysis in Interfirm Relationships: A Field Study. Management Accounting Research 14 (2003) 1-23.

[12] Mangifera, Liana. 2015. Analisis Rantai Nilai (Value Chain) Pada Produk Batik Tulis di Surakarta, Benefit Jurnal Manajemen dan Bisnis, Volume 19 No. 1, Juni, Halaman 24-33.

[13] Mardian, Novira Kusrini, dkk., 2012, Analisis Rantai Nilai (Value Chain) Pada Komoditas Lada di Desa Trigadu Kecamatan Galing Kabupaten Sambas" Jurnal Sains Mahasiswa Pertanian Vol. 2, No, 1, Halaman 1-9.

[14] Rieple, Alison dan Rajbir Singh. (2010). A Value Chain Analysis of the Organic Cotton Industry: The Case of UK Retailers and Indian Suppliers. Ecological Economics 69 (2010) 2292-2302.

[15] Zhou, Xingjian. 2013. Research on Logistic Value Chain Analysis and Competitiveness Construction for Express Enterprise. American Journal of Industrial and Bussines Management, 3. 131-135.

[16] Sopadang, Apichat, Karraket Y, Tippayawong, Waramol Chaowarut. 2012. Application of Value Chain Management to Logan Industry. American Journal of Agriculture and Biological Sciencess. 7 (3). 301-3011.

[17] Limakrisna dan Susilo. 2013. Manajemen Pemasaran Teori dan Aplikasi Dalam Bisnis, Jakarta, Mitra Wacana Media.

[18] Stanton, William J. 2011. Prinsip Pemasaran. Erlangga. Jakarta.

[19] Kotler, Philip. 2011. Manajemen Pemasaran di Indonesia: Analisis, Perencanaan, Implementasi dan Pengendalian. Salemba Empat. Jakarta.

[20] Sugiyono. 2011. Metode Penelitian Kuantitatif, Kualitatif dan R\&D. Bandung: Afabeta.

[21] Umar, Husein. 2013. Metode Penelitian untuk Skripsi dan Tesis. Jakarta: Rajawali.

[22] Olunke, Oni Timothy. 2013. Evalution of Income and Employment Generation from Cassava Value Chain in the Nigerian Agriculture Sector. Asian Journal of Agriculture and Rural Development, 3 (3). 79-92. 